\title{
The Efficiency of Exchange Rate Market: A Case Study on Pakistan
}

\author{
Zobia Israr Ahmed \\ Department of Economics, University of Karachi, Karachi, Pakistan \\ Email address: \\ xobiaisrarahmed@gmail.com
}

\section{To cite this article:}

Zobia Israr Ahmed. The Efficiency of Exchange Rate Market: A Case Study on Pakistan. International Journal of Economics, Finance and Management Sciences. Vol. 3, No. 2, 2015, pp. 125-137. doi: 10.11648/j.ijefm.20150302.17

\begin{abstract}
This study investigates the efficiency of foreign exchange market in Pakistan. Based on monthly data during the period of July 2000 to October 2012 for 13 currencies against the Pak Rupee, three techniques of regression analysis are applied. The result of regression on trended data portrayed that unbiased hypothesis does not hold in the exchange rate market owing to serial correlation and non-stationary time-series data. The regression analysis with de-trended data remarked exchange rate market of Pakistan is neither efficient nor speculative. The findings of regression analysis with orthogonality experiment explored incidence of bandwagon behavior in selected currencies. The results of this study suggested that concerned authorities should reinforce information dissemination procedure and regulate unofficial currency markets activities for maintaining the efficiency of foreign exchange market in Pakistan.
\end{abstract}

Keywords: Pakistan Exchange Rate Market, Market Efficiency, Fama Regression Analysis

\section{Introduction}

The efficiency of foreign exchange market entails market participants produce a bunch of exchange rates using all available information. This implies that the suitable value of exchange rate does not postulate any possibility to anomalous profit options. It means speculators or arbitrageurs who predict exchange rate on the basis of public information cannot produce super normal profits.

Pakistan followed numerous exchange rate regimes. Prior to 1971, Pak Rupee was allied with the Pound Sterling. However, in 1971 government proposed to ally the Rupee with US Dollar. Due to acute budget deficit as a result sudden drop in foreign remittances via legal ways which triggered large variances in Rupee per Dollar in 1981, Pakistan adopted managed floating exchange rate for lessening the disparity in official and black market rates. After nuclear test in 1998, Pakistan has been alleged by various international sanctions which caused devastating impact in foreign exchange flow in the country. Therefore, in order to manage such problems state bank of Pakistan followed three diverse rates consisting on; official rate in which Rupee was allied with Dollar at fix value, Floating Inter Bank Rate (FIBR) wherein commercial banks were permitted for quoting their rates, besides Composite rate following combination of official rate and floating interbank rates. However, that bunch of exchange rate regimes was abolished in 2000 after the introduction of floating exchange rate mechanism.

Exchange rate market in Pakistan has slightly increased in size especially the number of transactions has noticeably grown. Being an emerging economy, the foreign exchange volume of Pakistan is comparatively smaller than the rest of the world. However, with the increase in GDP size the volume of foreign exchange market is also growing. However, the evidence shows that the exchange rate market of Pakistan is still inefficient. Risk premium caused by the presence of $\mathrm{KERB}^{1}$ markets on one hand and frequently changing information due to political uncertainty have some inferences for the effectiveness of foreign exchange market. Indeed, the market uphold profitable opportunities as exchange rate market of Pakistan is dominated by US Dollar which generates cross real exchange rate influence on almost every currency exchange. Similarly, deficiency of instruments for market to hedge against risk exposure and mostly overestimated spot rates also supports the profitable

\footnotetext{
${ }^{1}$ A Kerb market is one where trading takes place outside official market hours. The expression comes from the practice in years gone by of trading on the Kerb in the street.
} 
options. Despite their consequence on exchange rate market, major macro-economic variables other than inflation and interest rates, are not imperative to the arbitrageurs in constructing exchange rate expectations.

The average daily volume of foreign exchange turnover is observed around $\$ 300$ million. The figure pertain the official channel (interbank market) and non-official channel (KERB market). It sometime overshadows activities of authorized market by crafting problems for its main supervisory body State Bank of Pakistan. While the data of transactions in the KERB markets is officially unavailable, however, unofficial sources estimate of average daily turnover of foreign exchange inflows. This is a major problem which financial market may face while examining efficient market hypothesis Central bank of Pakistan is trying to streamline this anomaly through formation of new exchange rate companies and by purchasing foreign exchange from KERB markets however still not succeeded in getting full control over this segment. Albeit, KERB market play significant role in shift of market flows and developing market attitude if government and state bank policies revise the demand and supply position of foreign currencies with respect to Pak Rupee.

Moreover, most of the times calculated spot rates are overstated. Certainly, the forward rate seems to contain risk premium however the sign of this premium move backward and forward most of the time. Consequently all these issues cause a wide impact while examining foreign exchange market efficiency. In this study we ask these questions; whether (i) currency's spot exchange rate reacts by way of a random walk, (ii) forward exchange rate become a neutral predictors of future spot rate for a selected currency, and (iii) incidence of bandwagon effect existing in the exchange rate market.

The organization of the paper follows a frame of presentation wherein section two contained review of literature. Section three presented the data requirements for testing coupled with methodology and model formulation. Results from the empirical study are estimated and discussed in section four. In the end, conclusions and policy recommendations followed in the section five.

\section{Review of Literature}

A lot of literature is available on the investigation of exchange rate market efficiency and the results of these studies are mixed. The pioneer study was conducted by Fama (1965) on the topic and found that if the market is efficient then a lot of exchange rates based on all available information bearing on the suitable value of exchange rate. He further identified that effectual markets never left vacant any possibility of earning huge returns. This is the most debatable matter of discussion in the exchange rate markets specifically. In latter study Fama (1984) further scanned the rationality of forward markets and deduced that both of these elements differ over time. In addition to that these fluctuations crop up due to inconsistency in the market premium, and projected the inverse relationship of future spot value and premium with the forward rate.

Levich (1979) performed an experiment on 20 values of floating rates and observed that exchange rate market is volatile therefore opportunities of huge gains are high. He concluded that markets generally attempt to follow all existing information although it did not reflect complete set of information in order to best forecast. In the earlier days many researchers have employed simple regression technique for testing the efficient market hypothesis during the decades of 1970s and the initial of 1980s which mainly includes Cornell (1977), Frankel (1981), and Bilson (1981).

Meng and Ahmad (2012) investigated the efficiency of Asia Pacific foreign currency markets. They employed Johansen co-integration technique and Fama's regression analysis. They found co-integration between forward and spot exchange rates. Based on bivariate co-integration they further determined that market is efficient across the countries. However, they applied multivariate technique they found market is inefficient.

The idea that speculation is stabilizing relates to the inference of Friedman (1953), whereas McKinnon (1976) uncovered insufficient inferences due to excessive unsteadiness in exchange rates. Cheung et al (2001) focused the variability, speculation and stability in the US foreign exchange market. The results indicated that speculations not only significantly amplify the instability but also impetus exchange rates to their primary values besides soaring up market liquidity and efficacy.

Timmermann and Granger (2004) expressed that hypothesis for market efficiency upsurge the prediction experiments from the specified set of information while investigating the best forecast. They pointed out that the existence of non-stationery behavior due to gainful chances in the financial market. In their recent study, Guerrien and Gun (2011), described that market efficiency hypothesis is universal and argued that it has not been explained by Fama in his publication produced in 1970 therefore that issue caused many ambiguities regarding its definition.

Bilson (1981) is applied rational expectation theory in the form of speculation efficiency theory and found that market is efficiently speculative when forward rates are equivalent to the projected spot money values if flows of reserves were perfectly elastic. Hartley (1983) examined the hypothesis that expectations of exchange rate movements are formed rationally. Stefano et al (1993) observed that forward discount instability is caused by the disparity in risk premium and found market contestants irrational in Asian currencies. In context of Pakistan Bhatti (1997), performed cointegration and coefficient restriction test and analyzing whether expectations contributed to determine the currency rates, and supported that viewpoint while assuming efficient markets having future expectations. The results also favored purchasing power parity inferring that currency rates pursued random walk.

In south Asian region Wickremasinghe (2004), examined weak and semi strong form efficiencies of exchange market in Sri Lanka. Used unit root tests for weak efficiency form 
and Granger causality tests and variance decomposition for semi strong efficiency his findings did not support for semi strong efficiency in Sri Lankan foreign exchange market. In later study Wickremasinghe (2008) he found more clear evidence of weak forms of efficiency for the foreign exchange market by using autocorrelation, Box-Pierce QStatistic familiar as Ljung-Box (LB) statistic.

Sasikumar (2011) examined the weak efficiency test in Indian foreign exchange market by applying variance ratio tests. Few analyses have been also conducted to explore the weak degree of efficiency of Pakistan foreign exchange market. Ahmed et al (2008) applied various unit root tests and variance ratio test for testing the weak form efficiency of SAARC countries exchange rate markets and found evidence of weak form of efficiency. Similarly, Chaudhry et al (2012) have examined weak-form efficiency using unit root tests and reported weak efficiency in South Asian foreign exchange markets. In the same experiment they examined semi-strong form using co-integration and Granger causality tests however results provided evidence against semi strong form of efficiency.

\section{Data and Methodology of the Study}

\subsection{Data}

The data used in this study is monthly covered from July 2000 to October 2012 for 13 currencies against the Pak Rupee. Those countries' currencies are selected whose are major export partners, major import partners or total trade partners to Pakistan. The data for spot and forward exchange rate is consist on monthly averages ${ }^{2}$ comprising the currencies- the Bangladeshi Taka (BDT), Chinese Yuan (CNY), European Common Currency (EURO), German Mark (DKK), Hong Kong Dollar (HKD), Indian Rupee (INR), Japanese Yen (JPY), Kuwaiti Dinar (KWD), Malaysian Ringgit (MYR), Saudi Arabian Riyal (SAR), UAE Dirham (AED), British Pound (GBP) and US Dollar (USD) against the Pak Rupee (PKR). The data set was obtained from the official website of State Bank of Pakistan (www.sbp.org.pk), apart from Bangladeshi and Chinese forward exchange rates against Pak Rupee were calculated through covered interest rate parity (CIP) condition $^{3}$ due to non-availability of information.

\subsection{Methodology}

This study is conducted the relationship between spot and forward exchange rates in selected currencies. This has observed that the economists are exercising regression methodology. In this regard, the researchers assumed that the

\footnotetext{
${ }^{2}$ Initially data was selected on daily basis, however the results earned from the data were not providing sufficient information, and therefore data was converted on monthly averages.

${ }^{3}$ Covered interest rate parity condition is the formula used by banks to calculate their forward exchange quotation by $F=\frac{\left(1+r_{d}\right) S}{\left(1+r_{f}\right)}$, where $r_{f}$ is one year foreign interest rate and $r_{d}$ is one year domestic interest rate. Data for interest rates are collected from World Bank official website.
}

financiers are risk neutral and therefore relates the expected value of future spot rate to the forward currency rate. This relation expressed in terms of equation which is given following;

$$
E\left(S_{t+1}\right)=f_{t, 1}
$$

Where $f_{t, 1}$,is the log of forward exchange rate at time $t$, and $E\left(S_{t+1}\right)$ is the log of expected value of spot exchange rate in one lead period of time. After the application of rational expectations for the forecast of future exchange rates, the equation (1) become as;

$$
S_{t+1}=E\left(S_{t+1}\right)+u_{t+1}
$$

Where $S_{t+1}$ is the log of spot exchange rate with one lead period of time, expressing local money value per unit of foreign exchange, and $u_{t+1}$ described the residual error term with normal distribution. By substituting the expected value of future spot exchange rate in equation (2), then;

$$
S_{t+1}=f_{t, 1}+u_{t+1}
$$

The above equation reveals that economic forecasters have rational potentials and foreign exchange have no evidence regarding risk premium. Therefore future value of spot exchange rate must be equivalent to the forward exchange rate in addition to random error term.

The above formulation constitutes the mutual investigation of both rationality and risk neutrality. Many studies such as Cornell (1977), Levich (1978) and Frenkel (1980) investigated this topic on the basis of regression analysis of $\log$ of future spot exchange rate $S_{t+1}$ and $f_{t, 1}$ the $\log$ of forward exchange rate. Therefore the equation (3) become as;

$$
S_{t+1}=a_{0}+a_{1} f_{t, 1}+u_{t+1}
$$

In the above equation the null hypothesis of forward exchange rate is considered as $a_{0}=0$ and $a_{1}=1$. Consistent with that experiment, forward rates are deliberated as impartial estimator of future value of existing currency rates when foreign exchange market is reflected as effective in the way that currency rates are exploiting maximum possible information set besides no risk advantage.

In order to determine the impartiality in forward exchange rates, it is essential to minimize the possibility of time fluctuating risk advantages in the market or the causes of inconsistency in coherent market opportunities. Many researches like as Hansen et al (1980), Bilson (1981), Meese et al (1982), Cumby et al (1984), Fama (1984) and Froot et al (1989), Levich (1989) has conducted the topic and contain risk premium by Frankel and Cornell. The equation (4) become;

$$
E\left(S_{t+1}\right)=f_{t, 1}+r p_{t}
$$


Where $r p_{t}$ denotes the risk premium on the foreign currency. After substituting the equation (5) into equation (3), the following result in terms of another equation drawn;

$$
S_{t+1}=f_{t, 1}+r p_{t}+\mathrm{u}_{\mathrm{t}+1}
$$

Then further researches have focused on the incidence of risk fluctuating advantages while conditional on the assumption that forward markets are rational. Algebraically, the regression equation will then be;

$$
\Delta S_{t+1}=a_{0}+a_{1} r p_{t}+\mathrm{u}_{\mathrm{t}+1}
$$

Where $\Delta S_{t+1}$ represents the change in log spot rate, which is future percentage devaluation expressed as $\left(S_{t+1}-S_{t}\right)$, while $\left(f_{t, 1}-S_{t}\right)$ is the forward risk premium $r p_{t}$ of the ex post depreciation, $S_{t}$ is the log of the spot exchange rate at time $t$, and $f_{t, 1}$ is the log of the one period forward exchange rate at time $t$. Now the more elaborate form of equation (7) is;

$$
\left(S_{t+1}-S_{t}\right)=a_{0}+a_{1}\left(f_{t, 1}-S_{t}\right)+\mathrm{u}_{\mathrm{t}+1}
$$

The equation (8) de-trends the equation (2) and constitute a more powerful test of the efficient market hypothesis (EMH), which explained that $x$ percent of currency's forward discount $\left(f_{t, 1}-S_{t}\right)$ must decreased by $x$ percent while the currency at forward premium $\left(S_{t+1}-S_{t}\right)$ must increase by $x$ percent.

The null hypothesis is $a_{0}=0$ and $a_{1}=1$. Since 1980 the above model is widely used in the study of risk-neutral efficient markets hypothesis. Equation (8) is considered as Fama's regression in which $a_{1}$ is not only significantly different from unity but found to be closer to negative unity.

The negative resultant of $a_{1}$ implies that extrapolations derived from forward premium are considered as incorrect even though no evidence of biasness observed. This finding means that it is profitable to trade against the prediction provided by the forward premium.

An alternative methodology has been followed for observing the best fit of regression model by inserting an additional variable. Therefore by adopting that technique the equation (3) can be re-designed as;

$$
S_{t+1}=a_{0}+a_{1} f_{t}+a_{2} f_{t-1}+\mathrm{u}_{\mathrm{t}+1}
$$

Where $f_{t-1}$ express the log of lagged forward exchange rate. For efficient market hypothesis $a_{1}$ should also restricted to be zero. The research conducted by Edwards (1983) in the US exchange rate market against European currencies was found very supportive of that model for market efficiency hypothesis.

However another move towards the conception of market efficiency has been followed by analyzing of residual errors amidst expected and actual future values of exchange rates. The new equation was considered as;

$$
u_{t+1}=a_{0}+a_{1} I_{t}+v_{\mathrm{t}+1}
$$

Where $u_{t+1}$ represents the forecast error, $I_{t}$ expressed group of information accessible at the given period, and $v_{t+1}$ is a residual error term. The coefficient $a_{1}$ should be equal to zero. This efficiency test is famous for orthogonality property and it refer that agents used all relevant information in making their precisions by averting expected forecast errors. Therefore orthogonality hypothesis is employed for analyzing whether the projection error $S_{t+1}-f_{t}=u_{t+1}$ is impartial of projected error of preceding duration of time $u_{t}=S_{t}-f_{t-1}$.Then this can be expressed in regression form as;

$$
\left(S_{t+1}-f_{t}\right)=a_{0}+a_{1}\left(S_{t}-f_{t-1}\right)+v_{\mathrm{t}+1}
$$

In this equation $v_{t+1}$ is a random normally distributed error. Equation (11) can be reshuffled and generated as:

$$
S_{t+1}=a_{0}+a_{1}\left(S_{t}-f_{t-1}\right)+a_{2} f_{t}+v_{\mathrm{t}+1}
$$

According to the market efficiency hypothesis of unbaisedness and risk neutrality then $a_{0}=0, a_{1}=0$ and $a_{2}$ ought to be equivalent to unity. This test has been performed by Frankel (1980).

\section{Estimation and Empirical Results}

\subsection{Descriptive Statistics}

Table 1 shows the descriptive statistics of monthly data for spot exchange rates for selected currencies of foreign exchange with respect to Pakistan. It indicates that the frequency distributions of selected foreign currencies are not normal. In a Gaussian distribution, the coefficients of Skewness in all selected foreign currencies are positive which indicates that all series are right skewed. However, the accurate zero value of coefficient of Skewness is fairly improbable for real world data sets. Therefore according to Bulmer (1979)for standard law defining the Skewness explained that Chinese Yuan (CNY), UAE (Dirham), Hong Kong Dollar (HKD), Japanese Yen (JPY), Kuwaiti Dinar (KWD), Malaysian Ringgit (MYR), Saudi Arabian Riyal (SAR), and US Dollar (USD) are moderately skewed because the coefficient of Skewness of these currencies lies between $+1 / 2$ and +1 . Moreover, the Bangladeshi Taka (BDT), European Common Currency (EURO), German Mark (DKK), Indian Rupee (INR), and British Pound (GBP) are symmetric because the coefficient of Skewness of these currencies lies between $-1 / 2$ and $+1 / 2$. The kurtosis coefficient is observed less than 3 which indicate that all selected foreign currencies are Platykurtic indicating that all series of selected foreign 
currencies are slim and has a long tail. The highest and lowest observed in Chinese Yuan (0.7335). coefficient of kurtosis is observed in Japanese Yen (2.2298)

Table 1. Descriptive Statistics for Monthly Average Spot Rates

\begin{tabular}{lllllllll}
\hline Currencies & Mean & Std. Dev. & Skewness & Kurtosis & CV & JB & Prob. & Obs. \\
\hline Bangladesh(Taka) & 1.0447 & 0.1157 & 0.0414 & 1.6970 & 11.0734 & 10.5121 & 0.0052 & 148 \\
China (Yuan) & 9.3439 & 2.7300 & 0.7335 & 0.7335 & 29.2167 & 20.8838 & 0.0000 & 148 \\
UAE (Dirham) & 18.7107 & 3.4401 & 0.7271 & 1.8274 & 18.3856 & 21.5185 & 0.0000 & 148 \\
EURO & 85.743 & 24.6280 & 0.2082 & 1.5740 & 28.7230 & 13.6092 & 0.0011 & 148 \\
Germany (Mark) & 11.5133 & 3.3051 & 0.2098 & 1.5760 & 28.7067 & 13.5897 & 0.0011 & 148 \\
Hong Kong(Dollar) & 8.8329 & 1.6374 & 0.7285 & 1.8289 & 18.5378 & 21.5494 & 0.0000 & 148 \\
India (RS) & 1.4856 & 0.2387 & 0.4938 & 1.7353 & 16.0662 & 15.8777 & 0.0004 & 148 \\
Japan (Yen) & 0.6857 & 0.2415 & 0.9117 & 2.2298 & 35.2239 & 24.1613 & 0.0000 & 148 \\
Kuwait (Dinar) & 238.2619 & 50.0828 & 0.6569 & 1.7758 & 21.0200 & 19.8860 & 0.0001 & 148 \\
Malaysia (Ringgit) & 19.7712 & 5.2332 & 0.8061 & 2.0777 & 26.4687 & 21.2721 & 0.0000 & 148 \\
Saudi Arabia(Riyal) & 18.325 & 3.3684 & 0.7273 & 1.8287 & 18.3812 & 21.5086 & 0.0000 & 148 \\
UK (Pound) & 114.5042 & 19.7311 & 0.0081 & 1.8069 & 17.2318 & 8.7804 & 0.0124 & 148 \\
US (Dollar) & 68.722 & 12.6361 & 0.7271 & 1.8274 & 18.3873 & 21.5208 & 0.0000 & 148 \\
\hline
\end{tabular}

Notes: This table shows means, standard deviations, skewness, kurtosis, coefficients of variation, Jarque-Bera and probabilities for the spot exchange rate variables. The sample consists on 148 average monthly observations of 13 currencies and the data covers the period from July 2000 to October 2012 . The critical value Jarque-Bera statistic for normality from a $\chi^{2}$ distribution with 2 degrees of freedom is 5.99 for the $5 \%$ level of significance.

Jarque Bera (JB) test demonstrates more evidently the normal distribution of series. All selected foreign currencies showed positive and higher value of Jarque Bera (JB). Generally, the distribution is perfectly normally distributed if the value for Skewness is zero, kurtosis value is three and the value of Jarque Bera is zero. Hence, the results obtained for Skewness and Platykurtic frequency distribution of foreign currencies specifies not normal distribution. Further, the coefficient of variation is employed for comparison of the variability of two series. The data for which the coefficient of variation is significantly high expresses that the variable is more volatile which implies that the series is less stable or less uniform. The highest coefficient of variation is found in Japanese Yen (JPY) and the lowest found in Bangladeshi Taka (BDT). It implies that Japanese Yen (JPY) is less consistent and Bangladeshi Taka (BDT) is more consistent. The same pattern is followed in forward exchange rates with one month maturity and is given in Table 2. This information provides a very clear signal of none existence of stationary process. (Follow Appendix I)

Table 2. Descriptive Statistics for Forward Rates with One Month Maturity.

\begin{tabular}{|c|c|c|c|c|c|c|c|c|}
\hline Currencies & Mean & Std. Dev. & Skewness & Kurtosis & $\mathrm{CV}$ & JB & Prob. & Obs. \\
\hline Bangladesh(Taka) & 1.0418 & 0.1173 & 0.0722 & 1.6863 & 11.2580 & 10.7708 & 0.0046 & 148 \\
\hline China (Yuan) & 9.3926 & 2.7594 & 0.7301 & 1.8796 & 29.3782 & 20.8876 & 0.0000 & 148 \\
\hline UAE (Dirham) & 18.8040 & 3.5082 & 0.7236 & 1.8179 & 18.6567 & 21.5332 & 0.0000 & 148 \\
\hline EURO & 86.1766 & 24.9558 & 0.2187 & 1.5678 & 28.9589 & 13.8282 & 0.0010 & 148 \\
\hline Germany (Mark) & 11.5700 & 3.3491 & 0.2204 & 1.5708 & 28.9461 & 13.7951 & 0.0010 & 148 \\
\hline Hong Kong(Dollar) & 8.8798 & 1.6700 & 0.7247 & 1.8165 & 18.8069 & 21.5942 & 0.0000 & 148 \\
\hline India (RS) & 1.4892 & 0.2402 & 0.4980 & 1.7325 & 16.1320 & 16.0256 & 0.0003 & 148 \\
\hline Kuwait (Dinar) & 238.9833 & 51.2461 & 0.6517 & 1.7665 & 21.4434 & 19.8604 & 0.0001 & 148 \\
\hline Malaysia (Ringgit) & 19.8601 & 5.2901 & 0.8004 & 2.0647 & 26.6368 & 21.1976 & 0.0000 & 148 \\
\hline Saudi Arabia(Riyal) & 18.4155 & 3.4386 & 0.7233 & 1.8167 & 18.6723 & 21.5373 & 0.0000 & 148 \\
\hline UK (Pound) & 114.9561 & 20.0837 & 0.0326 & 1.7850 & 17.4708 & 9.1292 & 0.0104 & 148 \\
\hline US (Dollar) & 69.0606 & 12.8947 & 0.7237 & 1.8156 & 18.6715 & 21.5704 & 0.0000 & 148 \\
\hline
\end{tabular}

Notes: This table shows means, standard deviations, skewness, kurtosis, coefficients of variation, Jarque-Bera and probabilities for the forward exchange rate variables. The sample consists on 148 average monthly observations of 13 currencies and the data covers the period from July 2000 to October 2012 . The critical value Jarque-Bera statistic for normality from a $\chi^{2}$ distribution with 2 degrees of freedom is 5.99 for the $5 \%$ level of significance.

Table 3. Export Import and Total Trade of selected countries with Pakistan

\begin{tabular}{|c|c|c|c|c|c|c|}
\hline & EXPORT & PERCENTAGEX & IMPORT & PERCENTM & TRADE & PERCENTTRADE \\
\hline Bangladesh & 662 & 2.6806 & 63 & 0.1557 & 725 & 1.1127 \\
\hline China & 2085 & 8.4427 & 4278 & 10.5731 & 6363 & 9.7656 \\
\hline $\mathrm{ECC}$ & 3399 & 13.7634 & 3511 & 8.6775 & 6910 & 10.6052 \\
\hline Hong Kong & 525 & 2.1259 & 504 & 1.2456 & 1029 & 1.5793 \\
\hline India & 333 & 1.3484 & 1253 & 3.0968 & 1586 & 2.4341 \\
\hline Japan & 226 & 0.9151 & 1557 & 3.8482 & 1783 & 2.7365 \\
\hline Malaysia & 229 & 0.9273 & 2156 & 5.3286 & 2385 & 3.6604 \\
\hline
\end{tabular}




\begin{tabular}{lllllll}
\hline & EXPORT & PERCENTAGEX & IMPORT & PERCENTM & TRADE & PERCENTTRADE \\
\hline Saudi Arabia & 456 & 1.8465 & 4796 & 11.8534 & 5252 & 8.0605 \\
UAE & 1947 & 7.8839 & 1947 & 4.8120 & 3894 & 5.9763 \\
UK & 1304 & 5.2802 & 699 & 1.7276 & 2003 & 3.0741 \\
US & 3949 & 15.9904 & 789 & 1.9500 & 4738 & 7.2717 \\
Total & 16360 & 66.2455 & 26532 & 65.5743 & 42892 & 65.8287 \\
\hline
\end{tabular}

Note: The import, export and total trade details of selected countries with Pakistan are from economic survey of Pakistan 2012.

\subsection{Regression Analysis Between Spot Exchange Rate and Forward Exchange Rate}

For the analysis of efficiency of foreign exchange market the regression focuses on the casual relationship between dependent variable and independent variable. The spot exchange rate with one lead period of time is taken as dependent variable and the forward exchange rate at time $\mathrm{t}$ as independent variable. The regression analysis concentrated on the hypotheses that the coefficient (intercept) $a_{0}$ is zero and the coefficient (slope) $a_{1}$ is equal to one. The regression result is reported in Table 4.
The coefficient of $a_{0}$ is statistically significant in Bangladeshi Taka (BDT), European Common Currency (EURO), German Mark (DKK), Hong Kong Dollar (HDK), Kuwaiti Dinar (KWD), Saudi Arabian Riyal (SAR), and British Pound (GBP). It indicates that the forward exchange rates is systematically over or under predict the future spot exchange rate, and rational economic agents use information to make systematic profit in these currencies.

Table 4. Exchange Rate Market Efficiency Test.

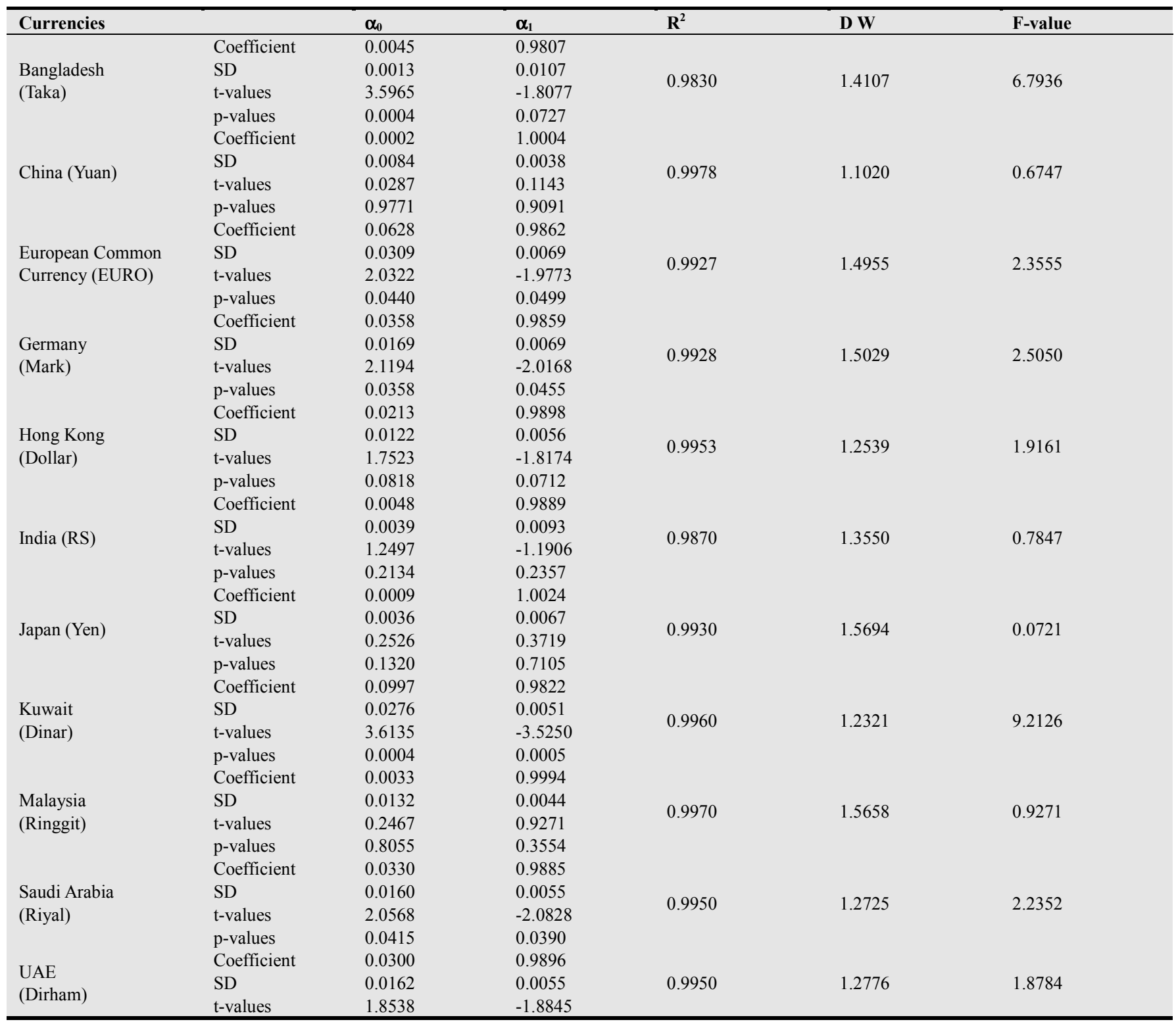




\begin{tabular}{|c|c|c|c|c|c|c|}
\hline Currencies & & $\alpha_{0}$ & $\alpha_{1}$ & $\mathbf{R}^{2}$ & D W & F-value \\
\hline \multirow{5}{*}{ UK (Pound) } & p-values & 0.0658 & 0.0614 & \multirow{6}{*}{0.9830} & \multirow{5}{*}{1.5758} & \multirow{5}{*}{2.5103} \\
\hline & Coefficient & 0.1110 & 0.9767 & & & \\
\hline & $\mathrm{SD}$ & 0.0504 & 0.0107 & & & \\
\hline & $t$-values & 2.1995 & -2.1821 & & & \\
\hline & p-values & 0.0294 & 0.0307 & & & \\
\hline \multirow{4}{*}{ US (Dollar) } & Coefficient & 0.0466 & 0.9888 & & \multirow{4}{*}{1.2475} & \multirow{4}{*}{2.0375} \\
\hline & $\mathrm{SD}$ & 0.0238 & 0.0056 & \multirow{3}{*}{0.9954} & & \\
\hline & t-values & 1.9689 & -1.9859 & & & \\
\hline & p-values & 0.0509 & 0.0489 & & & \\
\hline
\end{tabular}

Notes: This table estimates the following model; $S_{t+1}=a_{0}+a_{1} f_{t}+u_{t+1}$, for $t=1,2, \ldots \mathrm{T}$; and where $S_{t+1}$ is the log of actual spot rate in one month's period time; $f_{t}$ is the $\log$ current forward rate. Based on parameter estimates the hypothesis is that $a_{0}=0$ and $a_{1}=1$. In this table $R^{2}$ is calculated to observe the relationship between spot and forward rate.

The coefficient of $a_{0}$ is statistically insignificant for rest of currencies which pointed out that the role of information is poor and cannot make systematic profit in these currencies. If the coefficient $a_{1}$ is equal to unity it shows that forward exchange rate correctly predict the future spot exchange rate. However at 5 percent significance level null hypothesis for slope coefficient is rejected for EURO, German Mark (DKK), Kuwaiti Dinar (KWD), Saudi Riyal (SAR), UK Pound (GBP) and US Dollar (USD). It implies that forward exchange rate does not predict the future spot exchange rate. The remaining currencies have admitted the assumption that forward exchange rates are impartial conjecturers of future spots rates. Moreover, The coefficient of $a_{0}$ does not differ significantly from zero while the coefficient $a_{1}$ does not differ significantly from unit in Bangladeshi Taka (BDT), European Common Currency (EURO), German Mark (DKK), Hong Kong Dollar (HDK), Kuwaiti Dinar (KWD), Saudi Arabian Riyal (SAR), British Pound (GBP) and US Dollar (USD). The coefficient $\mathrm{R}$ square is very high in all currencies which indicate that all information has incorporated in forward exchange rate. Moreover, the joint hypothesis test has been performed for examining the efficiency of exchange rate market and none existence of risk premium in Pakistan. The F-statistic ${ }^{4}$ shows that the majority of the currencies have accepted the null hypotheses and identified rationality and risk neutrality. This is also noted that joint hypothesis is only denied for Bangladeshi Taka (BDT) and Kuwaiti Dinar (KWD). The values of Durbin-Watson test indicate that the exchange rate for Bangladeshi Taka (BDT), Chinese Yuan (CNY), European Common Currency (EURO), German Mark (DKK), Hong Kong Dollar (HDK), Indian Rupee (INR), Japanese Yen (JPY), Kuwaiti Dinar (KWD), Malaysian Ringgit (MYR), Saudi Arabian Riyal (SAR), British Pound (GBP) and US Dollar (USD) contain positive serial correlation which is sign of inefficient of exchange market. These results tell us that market manager could project future errors on the basis of past errors which are the symptom of exchange market inefficiency that there has been a significant chance identified for unexploited profit opportunities. Moreover, this is also found that Durbin Watson Static is greater than $\mathrm{R}^{2}$ which verify that regression analysis is not spurious.

\footnotetext{
${ }^{4}$ The value for F- statistic has been calculated through Wald test by employing coefficient Restriction where; $\alpha_{0}=0, \alpha_{1}=1$.
}

From the above analysis it is concluded that the unbiased hypothesis does not embrace in the Pakistani exchange rate market owing to existence of serial correlation substantiating either presence of a risk premium and/or that of market inefficiency. It is also observed that both $f_{t, 1}$ and $S_{t+1}$ are generated by non-stationary time-series processes, thus test conducted for equation (4) seemed incompatible with linear regression model. Therefore, the next technique to be followed is Fama's regression analysis by de-trending the sample data for keeping regression estimates unbiased and avoiding the non-stationery processes.

\subsection{Regression Analysis between Spot Exchange Rate and Forward Exchange Ratewith de-Trended Data}

In this experiment the de-trended data used in order to minimize the possibilities of non stationarity which is based on equation (8). The forward exchange rate market efficiency has been examined by regressing the four week change in the spot exchange rate as forward premium $\left(S_{t+1}-S_{t}\right)$ on the thirty days forward discount rate $\left(f_{t, 1}-S_{t}\right)$. The results are presented in Table 5. The coefficient of $a_{0}$ is observed statistically insignificant in, European Common Currency (EURO), German Mark (DKK), and Kuwaiti Dinar (KWD). It indicates that the forward discount rates not systematically over or under predicts the forward premium. If the coefficient $a_{1}$ is equal to unity it shows that average change in exchange rate is correctly forecast forward premium or discount. The slope coefficient of $a_{1}$ is witnessed statistically insignificant in European Common Currency (EURO), German Mark (DKK) and Kuwaiti Dinar (KWD). It implies that change in exchange rate is not correctly forecast forward premium or discount in above mentioned currencies. It infers that mostly available information is not used in a systematic manner in these currencies. The slope coefficient of $a_{1}$ is statistically significant in remaining currencies which indicates that change in exchange rate is correctly forecast forward premium or discount. The slope coefficient of $a_{1}$ is not only noticed significantly different from one but find to be closer to negative unity in various studies (Fama 1984; Froot \& Thaler, 1990; Sarno, 2005). Instead of providing an unbiased prediction to the changes of future spot rate, the negative 
slope coefficient of $a_{1}$ implies that the prediction provided by the forward premium is not only biased but also not correct. It implies that it is profitable to trade against the prediction provided by the forward premium. In this study only European Common Currency (EURO), German Mark
(DKK) proved this hypothesis. Most of the $a_{1}$ parameter results are positive concluding that Pakistan is an emerging economy. This finding is support to the finding of Bansal et al (2000) and Chinn et al (2005).

Table 5. Exchange market efficiency test with de-trended data.

\begin{tabular}{|c|c|c|c|c|c|c|}
\hline Currencies & & $\boldsymbol{\alpha}_{0}$ & $\alpha_{1}$ & $\mathbf{R}^{2}$ & DW & F-value \\
\hline \multirow{4}{*}{$\begin{array}{l}\text { Bangladesh } \\
\text { (Taka) }\end{array}$} & Coefficient & 0.0016 & 0.2337 & \multirow{4}{*}{0.0016} & \multirow{4}{*}{1.4209} & \multirow{4}{*}{6.4177} \\
\hline & SD & 0.0019 & 0.4785 & & & \\
\hline & t-values & 0.8376 & -1.6016 & & & \\
\hline & p-values & 0.4036 & 0.1114 & & & \\
\hline \multirow{4}{*}{ China (Yuan) } & Coefficient & -0.0014 & 1.5560 & \multirow{4}{*}{0.0561} & \multirow{4}{*}{1.1153} & \multirow{4}{*}{1.2234} \\
\hline & SD & 0.0027 & 0.5301 & & & \\
\hline & t-values & -0.5295 & 1.0490 & & & \\
\hline & p-values & 0.5972 & 0.2959 & & & \\
\hline \multirow{4}{*}{$\begin{array}{l}\text { European Common } \\
\text { Currency (EURO) }\end{array}$} & Coefficient & 0.0075 & -0.2988 & \multirow{4}{*}{0.0018} & \multirow{4}{*}{1.5284} & \multirow{4}{*}{2.9439} \\
\hline & SD & 0.0032 & 0.5763 & & & \\
\hline & t-values & 2.3199 & -2.2538 & & & \\
\hline & p-values & 0.0217 & 0.0257 & & & \\
\hline \multirow{4}{*}{$\begin{array}{l}\text { Germany } \\
\text { (Mark) }\end{array}$} & Coefficient & 0.0076 & -0.3110 & \multirow{4}{*}{0.0019} & \multirow{4}{*}{1.5327} & \multirow{4}{*}{3.0337} \\
\hline & SD & 0.0032 & 0.5795 & & & \\
\hline & t-values & 2.3657 & -2.2623 & & & \\
\hline & p-values & 0.0193 & 0.0251 & & & \\
\hline \multirow{4}{*}{$\begin{array}{l}\text { Hong Kong } \\
\text { (Dollar) }\end{array}$} & Coefficient & 0.0004 & 0.7595 & \multirow{4}{*}{0.0398} & \multirow{4}{*}{1.2344} & \\
\hline & SD & 0.0017 & 0.3096 & & & 05615 \\
\hline & t-values & 0.2437 & -0.7767 & & & 0.5011 \\
\hline & p-values & 0.8078 & 0.4386 & & & \\
\hline & Coefficient & 0.0028 & 0.0352 & & & \\
\hline India (RS) & SD & 0.0019 & 0.5666 & 00003 & 13511 & 15264 \\
\hline MUIa (IN) & $t$-values & 1.4397 & -1.7028 & $0.000 \mathrm{~S}$ & 1.5311 & 1.0204 \\
\hline & p-values & 0.1521 & 0.0907 & & & \\
\hline & Coefficient & 0.0039 & 0.3549 & & & \\
\hline Janan (Yen) & $\mathrm{SD}$ & 0.0047 & 0.6610 & 00010 & 15651 & 04791 \\
\hline Japan (Yen) & t-values & 0.8352 & -0.9757 & 0.0019 & 1.5051 & $0.4 / 91$ \\
\hline & p-values & 0.4050 & 0.3308 & & & \\
\hline & Coefficient & 0.0035 & 0.5582 & & & \\
\hline Kuwait & $\mathrm{SD}$ & 0.0011 & 0.1655 & 00727 & 11964 & 64582 \\
\hline (Dinar) & t-values & 3.1412 & -2.6683 & $0.0 / 21$ & 1.1904 & 0.4582 \\
\hline & p-values & 0.0020 & 0.0084 & & & \\
\hline & Coefficient & 0.0010 & 1.1231 & & & \\
\hline Malaysia & SD & 0.0017 & 0.3351 & 00710 & 15721 & 0.9862 \\
\hline (Ringgit) & t-values & 0.5628 & 0.3672 & 0.0719 & $1.5 / 21$ & 0.9862 \\
\hline & $\mathrm{p}$-values & 0.5745 & 0.7140 & & & \\
\hline & Coefficient & 0.0007 & 0.7563 & & & \\
\hline Saudi Arabia & SD & 0.0016 & 0.2877 & 00455 & 12482 & 04237 \\
\hline (Riyal) & $\mathrm{t}$-values & 0.4494 & -0.8471 & 0.0455 & 1.2482 & 0.4231 \\
\hline & p-values & 0.6538 & 0.3983 & & & \\
\hline & Coefficient & 0.0001 & 0.8714 & & & \\
\hline UAE & $\mathrm{SD}$ & 0.0016 & 0.2992 & 00552 & 12575 & 01929 \\
\hline (Dirham) & t-values & 0.0831 & -0.4299 & 0.0352 & $1.25 / 3$ & 0.1929 \\
\hline & p-values & 0.9339 & 0.6679 & & & \\
\hline & Coefficient & 0.0036 & 0.2595 & & & \\
\hline UK (Pound) & $\mathrm{SD}$ & 0.0025 & 0.4740 & 00021 & 15906 & 13475 \\
\hline Un (Pouna) & t-values & 1.4131 & -1.5620 & 0.0021 & 1.0900 & $1.04 / 5$ \\
\hline & p-values & 0.1598 & 0.1205 & & & \\
\hline & Coefficient & 0.0012 & 0.6583 & & & \\
\hline US (Dollar) & $\mathrm{SD}$ & 0.0016 & 0.2992 & 00323 & 12258 & 07168 \\
\hline US (Dollar) & t-values & 0.6961 & -1.1420 & 0.0323 & $1.2 \angle 58$ & 0.1108 \\
\hline & p-values & 0.4875 & 0.2553 & & & \\
\hline
\end{tabular}

Notes: This table estimates the following model; $\left(S_{t+1}-S_{t}\right)=a_{0}+a_{1}\left(f_{t, 1}-S_{t}\right)+u_{t+1}$ for $\mathrm{t}=1,2, \ldots \mathrm{T}$; and where $\left(S_{t+1}-S_{t}\right)$ is the log of change in actual spot rate in one period's time; $\left(f_{t, 1}-S_{t}\right)$ is the log current forward rate minus spot rate in one month's time. Based on parameter estimates the hypothesis is that $a_{0}=0$ and $a_{1}=1$. In this table $R^{2}$ is calculated to observe the relationship between de-trended spot and forward rate.

The joint hypothesis is statistically significant for all selected currencies which indicates that exchange rate market 
is rational and risk neutral. However, Pakistani exchange rate market is inefficient with the presence of risk premium for Bangladeshi Taka and Kuwaiti Dinar. The coefficient of determination $R^{2}$ for all models is observed very low signifying that available information is not properly and fully incorporated in the forward rates. However, the Durbin Watson statistic revealed presence of serial correlation in the regression of spot exchange rates with their lagged forward rates. It shows that non stationary process still existing in the de-trended sample data.

In Pilbeam's words, 'these results reveal that once the trend applied in the exchange rate, market partakers have on average mis-projected the trajectory of its movements". Hence, this is proposed that currencies at forward discount have actually strengthened by the incidence of first degree serial correlation between the residual errors. In this situation, by purchasing the currency of a country with extraordinary interest rates the customers can make profits, which were hence at a forward discount rate $\left(f_{t, 1}-S_{t}\right)$. Interest rate in Pakistani economy is observed comparatively higher than all selected majorly exporting, importing and totally trading countries with Pakistan. Therefore countries with whom particularly Pakistan have export transactions [Bangladesh, China, Germany, Hong Kong, India, United Kingdom and United States] are considerably gaining benefit both from high interest rates and currency value appreciation due to increase in inflation.

\subsection{Regression Analysis between Spot Exchange Rate and Forward Exchange Rate by Using Orthogonality Property.}

The regression analysis examines to get the drift if another variable that can improve the results of regression. Numerous analysts have considered distinct methodologies for this approach. Frankel (1980) conducted this approach famously known for orthogonality property and this is expressed by the equation (12). It implies that market managers exploit all accessible information in making their conjectures by avoiding predictable projection errors. According to the efficient market hypothesis if there is no risk advantage and foreign market exploits all information efficiently then null hypotheses of rationality and risk neutrality for forward exchange rate market from equation (12) implies that the coefficient of $a_{0}$ is zero, the coefficient of $a_{1}$ is zero, and the coefficient of $a_{2}=1$.

The results for the above test are reported in Table 6 . The overall findings indicated a slightly mixed result for foreign exchange market of Pakistan. The exchange rate market is significantly efficient with no risk premium for Japanese Yen (JPY) and Malaysian Ringgit (MYR). However, the results of remaining selected currencies decisively negate the joint hypotheses for efficiency due to the presence of risk premium. Non-stationary problem is still present in the model. However, the problem of autocorrelation has been properly accommodated. Moreover, relationship between future spot exchange rates and forward exchange rates is found very strong showing that all available information is to the large extent is utilized. Furthermore, no evidence of spurious regression analysis has noticed.

Table 6. Alternative Exchange Rate Market Efficiency Test.

\begin{tabular}{|c|c|c|c|c|c|c|c|}
\hline Currencies & & $\alpha_{0}$ & $\alpha_{1}$ & $\alpha_{2}$ & $\mathbf{R}^{2}$ & DW & F-value \\
\hline \multirow{4}{*}{$\begin{array}{l}\text { Bangladesh } \\
\text { (Taka) }\end{array}$} & Coefficient & 0.0034 & 0.2916 & 0.9816 & \multirow{4}{*}{0.9845} & \multirow{4}{*}{2.0554} & \multirow{4}{*}{9.4588} \\
\hline & $\mathrm{SD}$ & 0.0012 & 0.0792 & 0.0103 & & & \\
\hline & $\mathrm{t}$-values & 2.7332 & 3.6809 & -1.7818 & & & \\
\hline & p-values & 0.0071 & 0.0003 & 0.0768 & & & \\
\hline \multirow{3}{*}{ China (Yuan) } & Coefficient & 0.0001 & 0.4395 & 1.0002 & \multirow{3}{*}{0.9983} & \multirow{3}{*}{2.1729} & \multirow{3}{*}{12.0462} \\
\hline & $\mathrm{SD}$ & 0.0076 & 0.0746 & 0.0034 & & & \\
\hline & t-values & 0.0181 & 5.8943 & 0.0568 & & & \\
\hline \multirow{4}{*}{$\begin{array}{l}\text { European Common } \\
\text { Currency (EURO) }\end{array}$} & Coefficient & 0.0595 & 0.2467 & 0.9868 & \multirow{4}{*}{0.993} & \multirow{4}{*}{1.9737} & \multirow{4}{*}{5.0824} \\
\hline & $\mathrm{SD}$ & 0.0304 & 0.0799 & 0.0068 & & & \\
\hline & t-values & 1.9541 & 3.0889 & -1.9085 & & & \\
\hline & p-values & 0.0526 & 0.0024 & 0.0582 & & & \\
\hline \multirow{3}{*}{$\begin{array}{l}\text { Germany } \\
\text { (Mark) }\end{array}$} & Coefficient & 0.0337 & 0.2432 & 0.9867 & \multirow{3}{*}{0.9932} & \multirow{3}{*}{1.9752} & \multirow{3}{*}{5.0925} \\
\hline & SD & 0.0167 & 0.0799 & 0.0068 & & & \\
\hline & $\mathrm{t}$-values & 2.0224 & 3.0427 & -1.9392 & & & \\
\hline \multirow{4}{*}{$\begin{array}{l}\text { Hong Kong } \\
\text { (Dollar) }\end{array}$} & Coefficient & 0.0146 & 0.3610 & 0.9929 & \multirow{4}{*}{0.9960} & \multirow{4}{*}{2.1267} & \multirow{4}{*}{8.7274} \\
\hline & $\mathrm{SD}$ & 0.0114 & 0.0765 & 0.0052 & & & \\
\hline & t-values & 1.2836 & 4.7182 & -1.3403 & & & \\
\hline & p-values & 0.2013 & 0.0000 & 0.1822 & & & \\
\hline \multirow{4}{*}{ India (RS) } & Coefficient & 0.0047 & 0.3162 & 0.9891 & \multirow{4}{*}{0.9884} & \multirow{4}{*}{1.8248} & \multirow{4}{*}{5.7573} \\
\hline & SD & 0.0037 & 0.0801 & 0.0089 & & & \\
\hline & t-values & 1.2537 & 3.9448 & -1.2205 & & & \\
\hline & p-values & 0.2120 & 0.0001 & 0.2242 & & & \\
\hline \multirow{2}{*}{ Japan (Yen) } & Coefficient & 0.0001 & 0.2154 & 1.0007 & \multirow{2}{*}{0.9938} & \multirow{2}{*}{2.0674} & \multirow{2}{*}{2.3608} \\
\hline & SD & 0.0035 & 0.0821 & 0.0066 & & & \\
\hline
\end{tabular}




\begin{tabular}{|c|c|c|c|c|c|c|c|}
\hline Currencies & & $\alpha_{0}$ & $\alpha_{1}$ & $\alpha_{2}$ & $\mathbf{R}^{2}$ & DW & F-value \\
\hline \multirow{6}{*}{$\begin{array}{l}\text { Kuwait } \\
\text { (Dinar) }\end{array}$} & t-values & 0.0253 & 2.6240 & 0.1190 & \multirow{6}{*}{0.9967} & \multirow{6}{*}{2.1114} & \multirow{6}{*}{14.6685} \\
\hline & p-values & 0.9798 & 0.0096 & 0.9054 & & & \\
\hline & Coefficient & 0.0661 & 0.3749 & 0.9881 & & & \\
\hline & SD & 0.0265 & 0.0759 & 0.0048 & & & \\
\hline & $t$-values & 2.4920 & 4.9382 & -2.4428 & & & \\
\hline & p-values & 0.0138 & 0.0000 & 0.0157 & & & \\
\hline \multirow{4}{*}{$\begin{array}{l}\text { Malaysia } \\
\text { (Ringgit) }\end{array}$} & Coefficient & 0.0021 & 0.2101 & 0.9996 & \multirow{4}{*}{0.9973} & \multirow{4}{*}{2.0222} & \multirow{4}{*}{2.7556} \\
\hline & SD & 0.0129 & 0.0815 & 0.0044 & & & \\
\hline & $t$-values & 0.1652 & 2.5788 & -0.0833 & & & \\
\hline & p-values & 0.8690 & 0.0109 & 0.9337 & & & \\
\hline \multirow{4}{*}{$\begin{array}{l}\text { Saudi Arabia } \\
\text { (Riyal) }\end{array}$} & Coefficient & 0.0225 & 0.3505 & 0.9921 & \multirow{4}{*}{0.9961} & \multirow{4}{*}{2.1277} & \multirow{4}{*}{8.4181} \\
\hline & SD & 0.0153 & 0.0766 & 0.0052 & & & \\
\hline & t-values & 1.4890 & 4.5720 & -1.5166 & & & \\
\hline & p-values & 0.1387 & 0.0000 & 0.1315 & & & \\
\hline \multirow{4}{*}{$\begin{array}{l}\text { UAE } \\
\text { (Dirham) }\end{array}$} & Coefficient & 0.0206 & 0.3484 & 0.9927 & \multirow{4}{*}{0.9961} & \multirow{4}{*}{2.1212} & \multirow{4}{*}{8.0730} \\
\hline & SD & 0.0152 & 0.0768 & 0.0052 & & & \\
\hline & $\mathrm{t}$-values & 1.3529 & 4.5352 & -1.3836 & & & \\
\hline & p-values & 0.1782 & 0.0000 & 0.1685 & & & \\
\hline \multirow{4}{*}{ UK (Pound) } & Coefficient & 0.1045 & 0.2105 & 0.9780 & \multirow{4}{*}{0.9833} & \multirow{4}{*}{2.0284} & \multirow{4}{*}{3.9715} \\
\hline & SD & 0.0504 & 0.0805 & 0.0106 & & & \\
\hline & $t$-values & 2.0747 & 2.6153 & -2.0622 & & & \\
\hline & p-values & 0.0398 & 0.0099 & 0.0409 & & & \\
\hline \multirow{4}{*}{ US (Dollar) } & Coefficient & 0.0318 & 0.3636 & 0.9923 & \multirow{4}{*}{0.9960} & \multirow{4}{*}{2.1236} & \multirow{4}{*}{8.8994} \\
\hline & SD & 0.0222 & 0.0763 & 0.0053 & & & \\
\hline & $t$-values & 1.4330 & 4.7641 & -1.4509 & & & \\
\hline & p-values & 0.1540 & 0.0000 & 0.1489 & & & \\
\hline
\end{tabular}

Notes: This table estimates the following model; $S_{t+1}=a_{0}+a_{1}\left(S_{t}-f_{t-1}\right)+a_{2} f_{t}+v_{t+1}$ for $t=1,2, \ldots \mathrm{T}$; and where $s_{t+1}$ is the log of actual spot rate in one month's period time; $\left(s_{t}-f_{t-1}\right)$ is the orthogonalized exchange rates referring agents are using relevant information in making their decisions by avoiding errors. $f_{t}$ is the $\log$ current forward rate. Based on parameter estimates the hypothesis is that $a_{0}=0, a_{1}=0$ and $a_{2}=1$. In this table $R^{2}$ is calculated to observe the relationship between spot and forward rate.

The presence of risk premium denied orthogonality experiment for forward currency forecast errors as market agents are using all randomly available information in making their forecasts which are causing the predictable forecast errors. In return purchasers of the foreign currency are taking advantage of profit.

This is suggested that due to the presence of risk premium buyers of all selected major exporting countries ${ }^{5}$ currencies $^{6}$ and the currencies of countries ${ }^{7}$ having total trade ${ }^{8}$ terms with Pakistani Rupee are enjoying profitable opportunities with the consequences of high interest rates, inflation and presence of KERB markets. However, the currency of importing countries Japan and Malaysia found efficient and implies that these exchange rate markets are using all relevant available information. Besides this other two highly importing countries' currencies Kuwaiti Dinar (KWD) and Saudi Arabian Riyal (SAR) rejects the market efficiency or speculated and responded to the herd effect in the market. This has happened because of very frequent number of trade transactions by being largest importing countries of Pakistan.

These results reveal that Pakistani exchange rate market in general is neither efficient nor speculative due to the presence

\footnotetext{
${ }^{5}$ According to Economic survey of Pakistan 2011-12.

${ }^{6}$ i.e. Bangladeshi Taka (BDT), Chinese Yuan (CNY), EURO, German Mark (DKK), Indian Rupee (INR), UAE Dirham (AED), British Pound (GBP) and US Dollar (USD)

${ }^{7}$ [EURO, German Mark (DKK), Indian Rupee (INR), UAE Dirham (AED), British Pound (GBP) and US Dollar (USD)]

${ }^{8}$ According to Economic survey of Pakistan 2011-12.
}

of risk premium and non-stationary process. More importantly, it is observed that exchange rate market by and large uses randomly available information and frequently reflected on rumors. This experiment in a wide extent favored the existence of herd or bandwagon effect in the Pakistani exchange rate market for all selected currencies. The corroboration of the incidence of bandwagon or herd effect furthermore concluded that Pakistani exchange rate market is semi strongly efficient.

\section{Conclusion}

This study examines the efficiency of exchange rate market of Pakistan during the study period from July 2000 to October 2012 in which Pakistani exchange rate market has slightly increased in size and the number of transactions has noticeably grown. The results indicate that have the exchange rate market of Pakistan is still inefficient. The reasons are risk premium which are caused by the presence of KERB markets, and frequently changing information due to political uncertainty in the country have some inferences for the effectiveness of foreign exchange market. Pakistan exchange rate market supports the profitable opportunities even though Pakistan's economy is dominated by US Dollar which generates cross real exchange rate influence on almost every currency exchange. Similarly, deficiency of instruments for market to hedge against risk exposure and mostly overestimated spot rates also supports the profitable options. Despite their consequence on exchange rate market, major 
macro-economic variables other than inflation and interest rates, are not imperative to the arbitrageurs in constructing exchange rate expectations.

This study has identified some key issues that should be handled to improve the efficiency of the foreign exchange market in Pakistan.

Firstly the information should be disseminated and make realize the investors on the meaning of major macroeconomic tools and their implications to the economy. This would be productive for those investors who have deep interest and also to those who perform some role in price formation in the exchange rate market. These market players will be helpful for quality and improved information incorporation which in turn probably alter the exchange rate market behavior.

Secondly, the KERB markets- Non official channels of exchange rate markets are very active in the Pakistan. Central bank should intervene into these unofficial markets for regulating their activities.

Thirdly, by reducing exchange rate misalignments in restoring efficiency of exchange rate market of Pakistan. Market players have identified that continued central bank interventions and presence of KERB markets causing fluctuations in exchange rate without any noticeable variation in its fundamentals. Conversely, donor resource imbursement and other organizations like IMF, World Bank and USAID etc. may also affect the directions exchange rates. Therefore, increase in export generating activities and tax revenue base could help in reducing the dependency on donor financings and their repercussions for exchange rates.

As final remarks, the government and central bank should make informed to take actions to reduce exchange rate volatility and evaluate the outcomes of numerous economic policies for exchange rates.

Appendix I. Trend Graphs of Average Monthly Spot Rates and One Month Maturity Forward Rates for the Selected Currencies
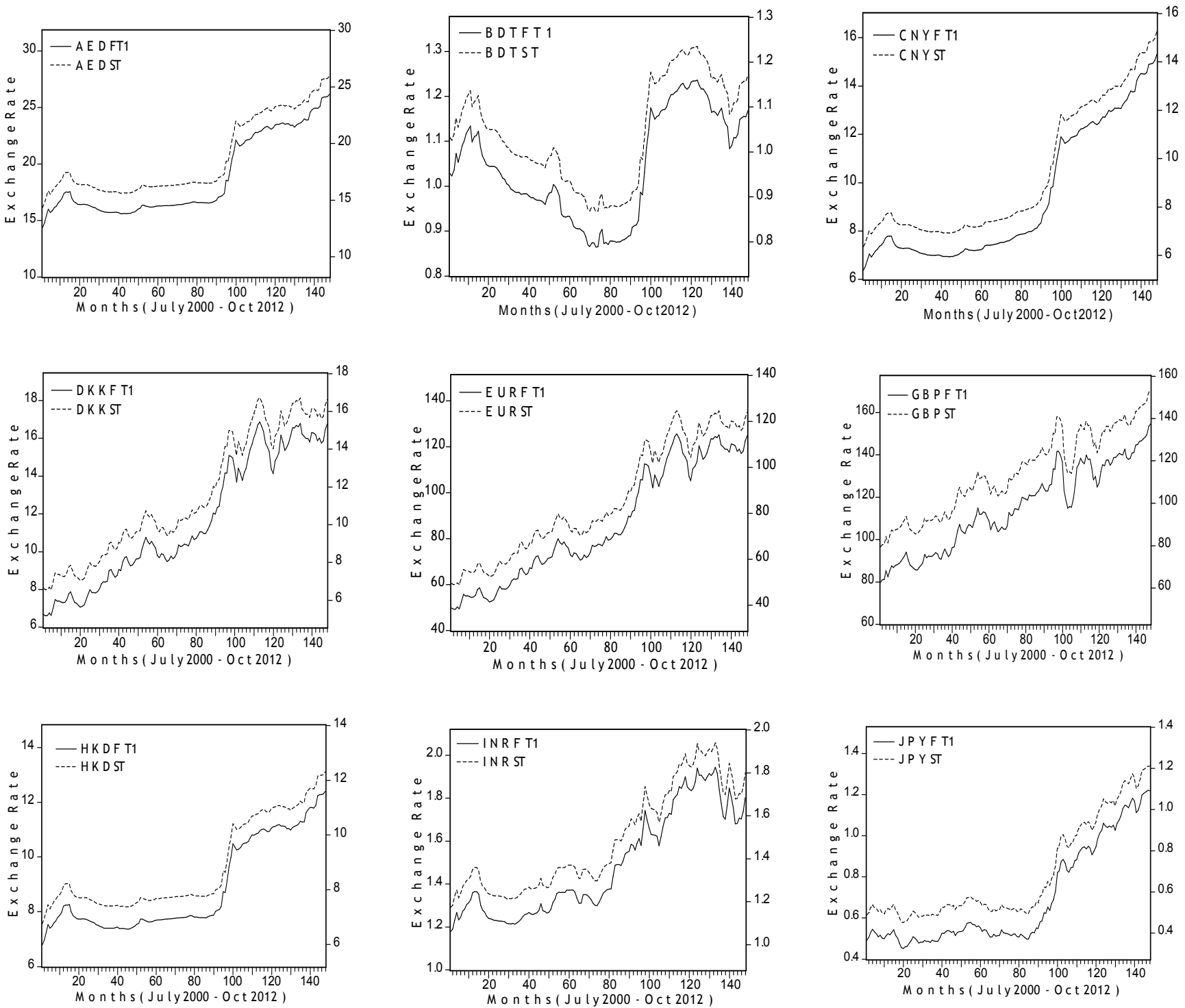

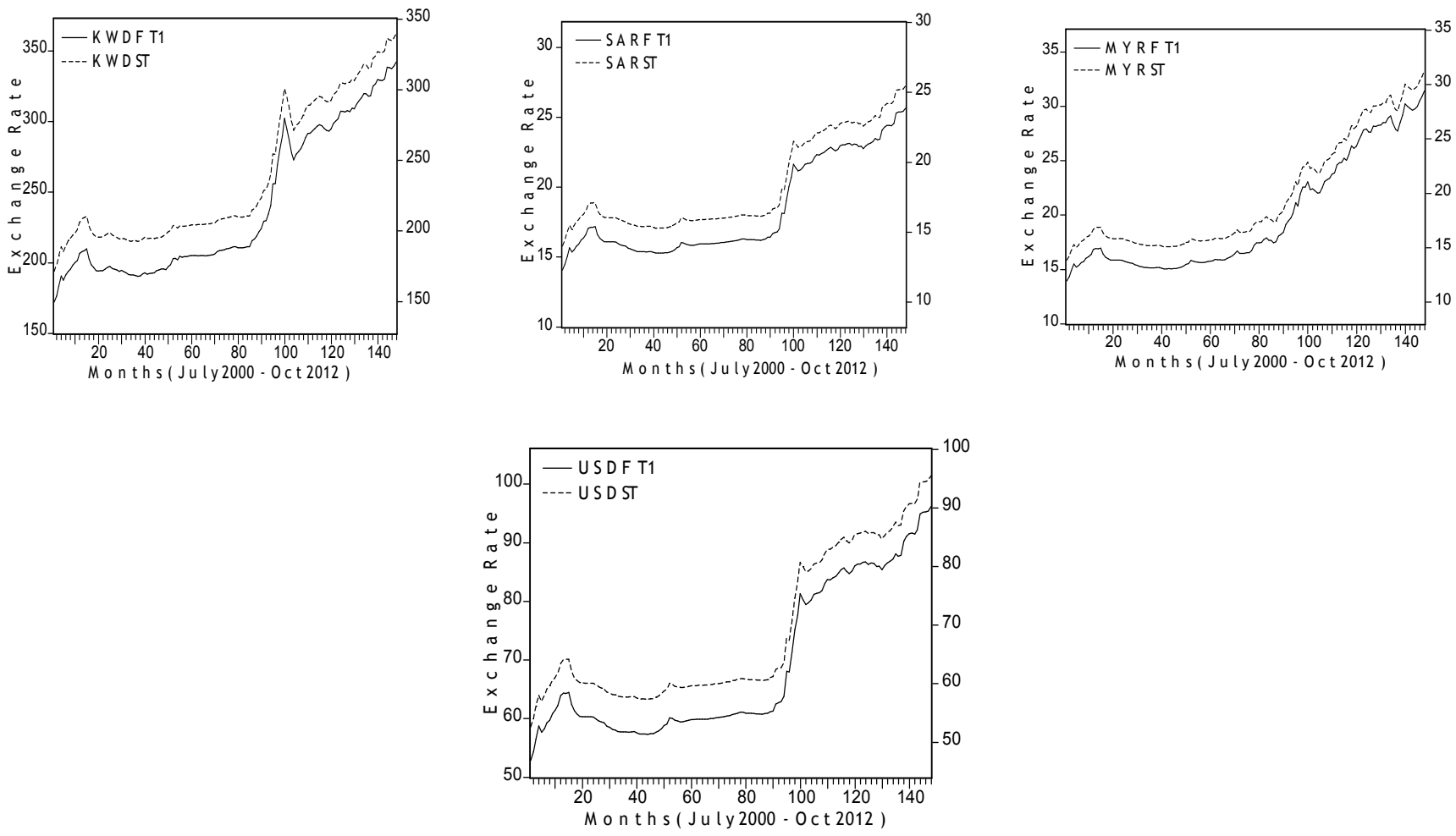

\section{References}

[1] Ahmed, H. 2009.Capital flows and real exchange rate overvaluation-a chronic ailment: Evidence from Pakistan. The Lahore Journal of Economics, 14: 51-86.

[2] Ahmed, K. M., Ashraf, S., \& Ahmed, S. 2007. Efficiency of foreign exchange markets: Evidence from south Asian countries. Indian Journal of Economics, 88(3): 17-33.

[3] Ahmad, R., Rhee, S. G., \& Wong, Y. M. 2012. Foreign exchange market efficiency under recent crises: Asia-pacific focus. Journal of International Money and Finance, 31(6): 1574-1592.

[4] Alajbeg, D., Bubaš, Z. \& Šonje, V. 2012. The efficient market hypothesis: problems with interpretations of empirical tests. Financial Theory and Practice, 36(1): 53-72.

[5] Akinlo, A. E. (2004). Foreign direct investment and growth in Nigeria: An empirical investigation. Journal of Policy Modeling, 26, 627-639.

[6] Bhatti, R. H. 1997. Do expectations play any role in determining Pak rupee exchange rates? The Pakistan Development Review, 36(3): 263-273.

[7] Bilson, J. F. O. 1981. The Speculative efficiency hypothesis. Journal of Business, 54(3): 435-451.

[8] Bilson, J. F. O. 1985. Macroeconomic stability and flexible exchange rates. The American Economic Review, 75(2): 62-67.

[9] Burton G. M. 2003. The efficient market hypothesis and its critics. Journal of Economic Perspectives, 17(1): 59-82.

[10] Chaudhry, S. A., \& Javid, A. Y. 2012. Efficiency of the foreign exchange markets of South Asian countries. PIDE Working Paper, 2012(82).
[11] Cheung, Y.-W., \& Wong, C. Y.-P. 2000. A survey of market practitioners' views on exchange rate dynamics. Journal of International Economics, 51: 401-419.

[12] Cheung, Y.-W., \& Chinn, M. D. 2001. Currency traders and exchange rate dynamics: a survey of the US market. Journal of International Money and Finance, 20: 439-471.

[13] Chinn, M. D., \& Frankel, J. A. 2002. Survey data on exchange rate expectations: More currencies, more horizons, more tests. Monetary policy, capital flows and exchange rates: essays in honor of Maxwell Fry.-London, 145-167.

[14] Edwards, S. (1989). "Exchange rate misalignment in developing countries." The World Bank Research Observer 4(1): 3-21.

[15] Ego, M.A, \& Sebudde, R. K. 2003. Measuring efficiency of a market in transition: The Ugandan foreign exchange market. Research series No. 33, Bank of Uganda.

[16] Fama. E. F. 1965. The behavior of stock-market prices. Journal of Business, 38(1): 34-105.

[17] Fama. E. F. 1984. Forward and spot exchange rates. Journal of Monetary Economics, 14: 319-338.

[18] Fama. E. F. 1991. Efficient markets: II. Journal of Finance, (5th Anniversary Invited Paper), 46:1575-1617.

[19] Fama. E. F. 1998. Market efficiency, long-term returns, and behavioral finance. Journal of Financial Economics, 49: 283306.

[20] Frankel, J. A., \& Chinn, M. D. 1993. Exchange rate expectations and the risk premium: Tests for a cross section of 17 currencies. Review of International Economics, 1(2): 136144. 
[21] Hai, W., Mark, N. C., \& Wu, Y. 1997. Understanding spot and forward exchange rate regressions. Journal of Applied Econometrics, 12: 715-734.

[22] Hamid, K., Suleman, M. T., Shah, S. Z. I., \& Akash, R. S. I. 2010. Testing the weak form of efficient market hypothesis: Empirical evidence from Asia-Pacific markets. International Research Journal of Finance and Economics, ISSN 14502887: 58

[23] Hansen, L. P., \& Hordick, R. J. 1983. Risk averse speculation in the forward foreign exchange market: An econometric analysis of linear models. University of Chicago Press, ISBN: 0-226-262 50-2: 113-152.

[24] International Monetary Fund website, www.imf.org

[25] Lee, Y.-H., \& Khatanbaatar, S. (2012). Efficiency tests in foreign exchange market. International Journal of Economics and Financial Issues, 2(2), 216-224.

[26] Levich, R. M. 1979. Analyzing the accuracy of foreign exchange advisory services: Theory and evidence. National Bureau of Economic Research, working paper no. 336.

[27] Meng, W. Y. \& Ahmed, R. 2011. Foreign exchange market efficiency in Asia Pacific: 1997-2010. European Financial Management Symposium 2011 Asian Financial Management.

[28] Ministry of Finance, Government of Pakistan website, www.finance.gov.pk

[29] Nasir, S., \& Hanif, M. 2012. Testing weak form of efficient market hypothesis: empirical evidence from South-Asia. World Applied Sciences Journal, 17(4): 414-427.

[30] Noman, A. M., \& Ahmed, M. U. 2008. Efficiency of the foreign exchange markets in south Asian countries. AIUB Business \& Economics Working Paper Series, 2008(18).

[31] Oh, G., Kim, S., \& Eom, C. (2007). Market efficiency in foreign exchange markets. Physica A: Statistical Mechanics and its Applications, 382(1), 209-212.

[32] Pilbeam, K. 1991. Exchange Rate Management: Theory and Evidence, London: Macmillan.

[33] Polito, E. 2001. Is the forward exchange rate a useful indicator of the future exchange rate? Issues in Political Economy, 2001(10).
[34] Rapp, T. A., \& Sharma, S. C. 1999. Exchange rate market efficiency: Across and within countries. Journal of Economics and Business, 51: 423-439.

[35] Rose, N. W., Kisaka, S. E., Ganesh, P., \& Gituro, W. 2008. An analysis of the efficiency the foreign exchange market in Kenya. Economics Bulletin, 14(2): 1-13.

[36] Sasikumar, A. 2011. Testing for weak form market efficiency in Indian foreign exchange market. Munich Personal RePEc Archive, Paper No. 37071.

[37] Sewell, M. 2011. History of the efficient market hypothesis. University College London-Department of Computer Science, $\mathrm{RN} / 11 / 04: 1-14$.

[38] Siddiqui, M. A. 2009. Modelling pak rupee volatility against five major currencies in the perspective of different exchange rate regimes. European Journal of Economics, Finance And Administrative Sciences, ISSN 1450-2275 Issue 17: 81-96.

[39] Siddiqui, R., \& Akhtar, N. 1999. The impact of changes in exchange rate on prices: a case study of Pakistan. The Pakistan Development Review, 38(4 Part II): 1059-1066.

[40] Stefan, I. 2009. Testing the efficient markets hypothesis: A behavioral approach to the current economic crisis. Senior Honors Thesis. University Of California.

[41] Timmermann, A. \& Granger, C. W. J. 2004. Efficient market hypothesis and forecasting. International Journal of Forecasting, 20: 15-27.

[42] Trading Economics website, www.tradingeconomics.com

[43] Waheed, M. 2009. Forward rate unbiased hypothesis, risk premium and exchange rate expectations: estimates on Pakistan Rupee-US Dollar. Munich Personal RePEc Archive, Paper No. 33167.

[44] Wickremasinghe, G. B. 2005. Efficiency of foreign exchange markets: A developing country perspective. Asian Academy of Management Journal, 10: 1-17.

[45] Wickremasinghe, G. B. 2008. Predictability of exchange rates in Sri Lanka: A test of the efficient market hypothesis. Asian Academy of Management Journal of Accounting and Finance, 3(2): 43-59.

[46] World Bank website, www.worldbank.com 